\title{
Effect of Sowing Rate on Agronomic Traits of Sorghum (Sorghum bicolor Moench) in Southern Kyushu, Japan
}

\author{
Sachiko Idota ${ }^{*}$, Yasuyuki Ishii ${ }^{1}$, Mayumi Izu², Yukistugu Nishimura ${ }^{2}$ \\ ${ }^{1}$ Faculty of Agriculture, University of Miyazaki, Miyazaki, Japan \\ ${ }^{2}$ Kaneko Seeds Co., LTD, Maebashi, Japan \\ Email: "sidota@cc.miyazaki-u.ac.jp, yishii@cc.miyazaki-u.ac.jp, m-izu@kanekoseeds.jp, \\ corn-seed@kanekoseeds.jp
}

Received 3 May 2016; accepted 20 May 2016; published 23 May 2016

Copyright (C) 2016 by authors and Scientific Research Publishing Inc.

This work is licensed under the Creative Commons Attribution International License (CC BY). http://creativecommons.org/licenses/by/4.0/

c) (7) Open Access

\begin{abstract}
Newly released sudangrass-type sorghum cv. "Tarzan" was bred for use as a bioenergy-resource feedstuff in Germany. Since the genotype was collected at a high altitudinal site in the Central Africa continent, its early growth is vigorous at low temperature. As vigorous growth at low temperature is derived from high tillering ability, the sowing rate of this genotype should be reduced from the ordinary rate for sorghum. Thus, in the present study, the optimal sowing rate of $\mathrm{cv}$. "Tarzan" in southern Kyushu was determined by the effect of sowing rate at $0.5,1.0$, and $1.5 \mathrm{~g} \cdot \mathrm{m}^{-2}$, designated as low (L), middle (M), and high (H) levels, respectively, on growth habit compared with the normal sudangrass cultivar "Roll-king II". Early growth was retarded by heavy precipitation in June, after which the growth was comparable for the two genotypes. Dry matter yield of "Tarzan" increased with higher sowing rate; the $\mathrm{H}$ level yield was $1298 \mathrm{~g} \cdot \mathrm{m}^{-2}$, and the yield was not adversely affected by the humidity and heat in the summer growing season, compared with "Roll- king II". This suggests that "Tarzan" can adapt to the humid, hot climate in southern Kyushu, and the optimum sowing rate of "Tarzan" should be as low as $1.0-1.5 \mathrm{~g} \cdot \mathrm{m}^{-2}$, which is less than onefifth to one-third that of forage sudangrass grown in the region.
\end{abstract}

\section{Keywords}

Dry Matter Yield, Genotype, Sorghum bicolor, Sowing Rate

\footnotetext{
${ }^{*}$ Corresponding author.
}

How to cite this paper: Idota, S., Ishii, Y., Izu, M. and Nishimura, Y. (2016) Effect of Sowing Rate on Agronomic Traits of Sorghum (Sorghum bicolor Moench) in Southern Kyushu, Japan. Agricultural Sciences, 7, 308-314. 


\section{Introduction}

Japanese self-sufficiency ratios of concentrate feed and roughage are now as low as $12 \%$ and $77 \%$, respectively [1], supported by a large amount of livestock feed imported from foreign countries. Therefore, several research studies of the cropping system and cultivation system were conducted for the Kyushu [2] and Kanto [3] regions, which were intended to promote an increase in the self-sufficiency ratio in Japan. Sorghum (Sorghum bicolor Moench) is a $\mathrm{C}_{4}$ annual crop, and grain sorghum has been a major staple food crop in African and Asian countries. This crop originated from the African continent, from which many current cultivars were originally introduced all over the world [4]. Sorghum can adapt to tropical, subtropical, and temperate climates [5] [6], while it is sensitive to chilling temperatures [7] [8], which significantly decrease the germination percentage and shoot and root dry weights of the crop [9]. Sorghum is also a prominent forage crop growing in many regions of the world [10] and can adapt to heat and drought conditions better than maize [11]. Thus, sorghum is now used for silage and hay production for livestock in warm regions such as western and southern Japan [12]. In Europe, notably Germany, Austria, and Italy, where biogas is the main source of bioenergy, sorghum has recently drawn attention as a bioenergy crop [13]. The new cultivar "Tarzan" was bred for bioenergy feedstuff in Einbeck, Germany $\left(52^{\circ} \mathrm{N}, 09^{\circ} \mathrm{E}\right)$. Since the genetic resources used to breed this cultivar were collected at high altitudinal sites in central Africa, "Tarzan" can grow vigorously at lower temperatures than cultivars currently available in Japan. Optimum sowing temperature for forage sorghum in Japan is over $15^{\circ} \mathrm{C}$, which is the critical temperature in Kyushu, Japan in early May. Therefore, this cultivar has the potential to be sown earlier than the conventional sowing season of the sorghum crop in Kyushu. The suitability of the cultivar "Tarzan" to central and northern European countries may be derived from a high tillering ability at lower temperature, which has allowed the sowing rate to be reduced to as low as 0.8 to $1.0 \mathrm{~g} \cdot \mathrm{m}^{-2}$ in Germany [14]. However, little information is available on the growth habit of the genotype cultivated in southern Kyushu, Japan. Therefore, the current study aimed to determine the optimum sowing rate of "Tarzan" as a forage crop in southern Kyushu, which was compared with the current sudangrass cultivar "Roll-king II".

\section{Materials and Methods}

\subsection{Genotypes Examined}

Sudangrass-type sorghum cultivar "Tarzan”, a novel genotype cultivated in Kyushu, Japan, and conventional sudangrass cultivar "Roll-king II" were compared for growth and yield attributes in a field trial. Cultivar "Rollking II" is a successor of the sudangrass cultivar "Roll-king", which is designated as the recommended forage sorghum cultivar in Fukuoka Prefecture, Japan, and has a thin stem suitable for making roll-bale hay and haylage. "Roll-king II" has the ability to produce high yield in relatively short growing season. It has fine stem than grain sorghum, along with having excellent regrowth after harvest. And this variety has high leaf yield that is palatable to livestock. Both of "Tarzan" and "Roll-king II" have disease tolerance to purple leaf spot.

\subsection{Plot Design and Plant Culture}

The experiment was carried out in an experimental field of the University of Miyazaki in southern Kyushu, Japan $\left(31.82^{\circ} \mathrm{N}, 131.40^{\circ} \mathrm{E}\right)$ in 2014 . The field was newly established at the end of March 2014, and no cultivation was carried out before the current experiment. Plot size was $9 \mathrm{~m}^{2}$, with $0.5 \mathrm{~m}$ space between plots. The plot was arranged in a completely randomized block design with three replications. The treatment for sowing rate was three levels of $0.5,1.0$, and $1.5 \mathrm{~g} \cdot \mathrm{m}^{-2}$ for $\mathrm{L}, \mathrm{M}$, and $\mathrm{H}$ levels, respectively. The two genotypes of sorghum were ridge-sown at $0.5 \mathrm{~m}$ intervals on 6 June 2014 and fertilized basically with $2.1 \mathrm{~g} \cdot \mathrm{m}^{-2}$ each of $\mathrm{N}, \mathrm{P}_{2} \mathrm{O}_{5}$, and $\mathrm{K}_{2} \mathrm{O}$ by a chemical compound fertilizer (Sumitomo Chemical Co. Ltd., Tokyo, Japan) and lime $\left(100 \mathrm{~g} \cdot \mathrm{m}^{-2}\right)$. Each plot was fertilized with $0.7 \mathrm{~g} \cdot \mathrm{m}^{-2}$ each of $\mathrm{N}, \mathrm{P}_{2} \mathrm{O}_{5}$, and $\mathrm{K}_{2} \mathrm{O}$ with topdressing of the same fertilizer twice on 25 July and 2 September, 2014. Weeding was conducted manually several times as required.

\subsection{Measurement of Plant Growth}

Sorghum genotypes were harvested at $10 \mathrm{~cm}$ above the ground level at the first and second cutting on 2 September and 2 November, 2014, respectively. Plants were fractionated to leaf blade (LB), stem (ST), and dead leaves (D). Fresh matter weight, dry matter weight (DMW), plant height (PH), plant length (PL), and tiller density 
of the first- and second-cut plants were determined at monthly intervals. Purpura spot disease incidence and plant lodging were scored on a scale of 1 to 9 during observation for growth attributes.

\subsection{Statistical Analysis}

Analysis of variance was performed using Excel Statistics (OMC Co. Ltd., Saitama, Japan). Differences in mean values were assessed at the $5 \%$ probability level using the Tukey-Kramer method.

\section{Results}

\subsection{Climatic Conditions}

The mean air temperature in the experimental period was $22.6^{\circ} \mathrm{C}$, and total precipitation was $1911 \mathrm{~mm}$ (Figure 1); the temperature was similar to a normal year, while the precipitation in June and August was higher than normal. After sowing, the early growth of sorghum was adversely affected by the high amount of rainfall. A typhoon approached quite close to the site in August, but lodging of plants was not observed in either variety.

\subsection{Plant Growth}

No symptoms of plant diseases appeared in either variety throughout the growing season. Plant length in both varieties changed similarly over time, as shown in Figure 2, and increased from July to September at a rate of $1.8-1.9 \mathrm{~cm} \mathrm{day}^{-1}$. Plant length did not differ significantly among treatments in "Tarzan", while length of "Roll-king II" tended to be higher in the M treatment than in the other treatments. After the first cutting, plant length did not differ significantly among treatments in either variety. In October, regrowth tiller density of "Tarzan" increased with sowing rate, with a smaller difference among treatments in November. In "Roll-king II", regrowth tiller density in the $\mathrm{M}$ treatment tended to be lower than in the other treatments and was significantly lower $(\mathrm{P}<0.05)$ in November. Across sowing rates, tiller density of "Tarzan" was significantly lower than that of 'Roll-king II', except for the $\mathrm{M}$ treatment in both October and November and the $\mathrm{H}$ treatment in October.

\subsection{Dry Matter Weight}

In the first cutting, the leaf-stem ratio range was 0.5 - 0.6 in "Tarzan" and $0.4-0.6$ in "Roll-king II". The dry weight of "Tarzan" increased with sowing rate until the first cutting, being highest in the $\mathrm{H}$ treatment and significantly higher than in the $\mathrm{L}$ treatment in July and September $(\mathrm{P}<0.05)$, while the difference among treatments was not significant in the second cutting (Figure 3). The dry weight of 'Roll-king II' tended to increase with sowing rate, although the differences were not significant in the first or second cutting. Annual total dry matter yield of "Tarzan" and "Roll-king II" was 1298 and $1209 \mathrm{~g} \cdot \mathrm{m}^{-2}$, respectively.

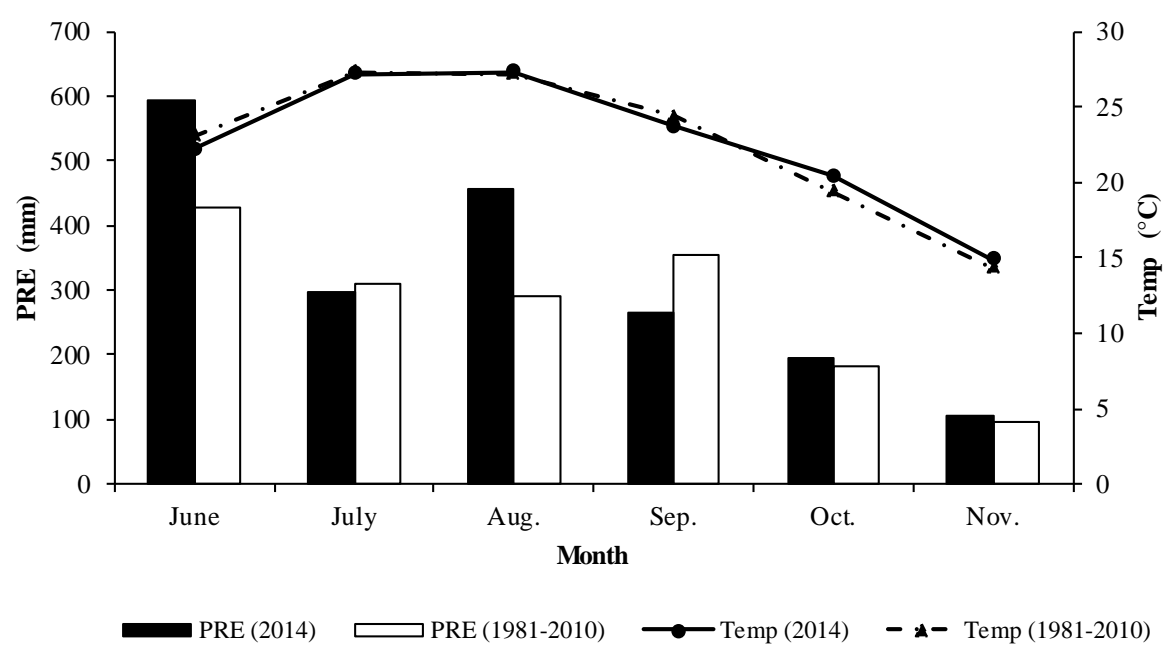

Figure 1. Changes in the mean air temperature (Temp, •) and precipitation (PRE, $\square)$ in growing season in 2014 and the normal year (averaged in 1981-2010). 


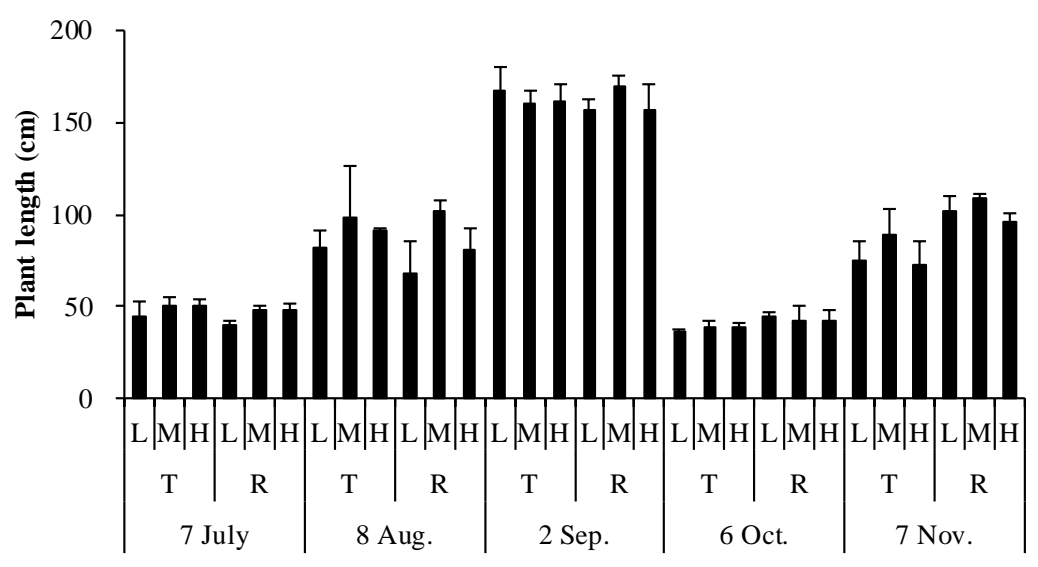

Date, variety and treatment

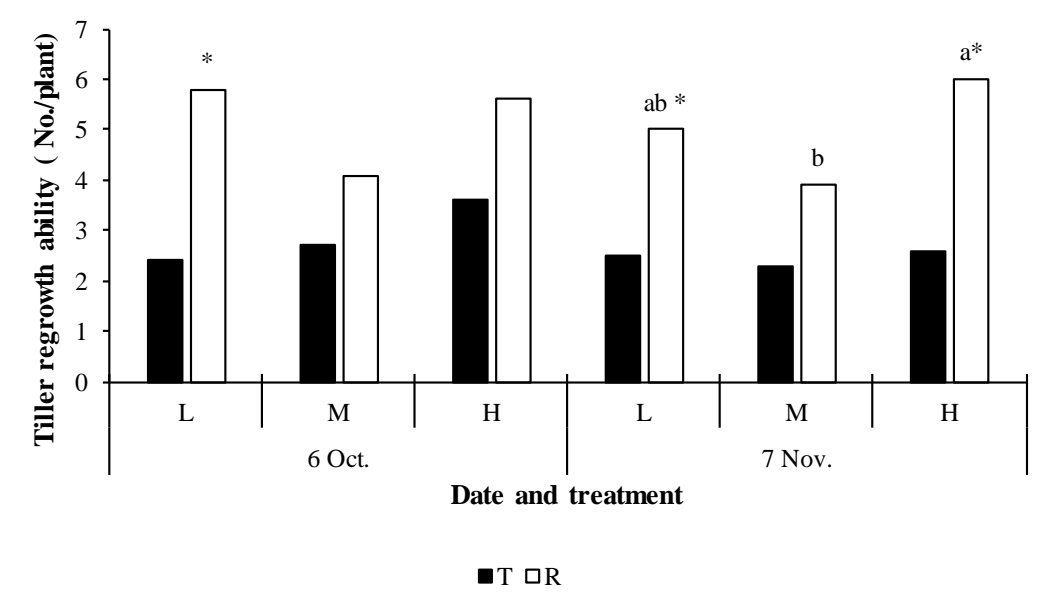

Figure 2. Changes in plant length and tiller regrowth ability in sorghum plants under different sowing rate on 6 June 2014. Sowing rate: $0.5(\mathrm{~L}), 1.0(\mathrm{M})$ and $1.5(\mathrm{H}) \mathrm{g}$ per $\mathrm{m}^{2}$. T: Tarzan, R: Roll-king II. *: $\mathrm{p}<0.05$ between varieties on the same treatment by Student's t-test. Symbols with different letters denote significant difference among treatments on the same date at the $5 \%$ level.

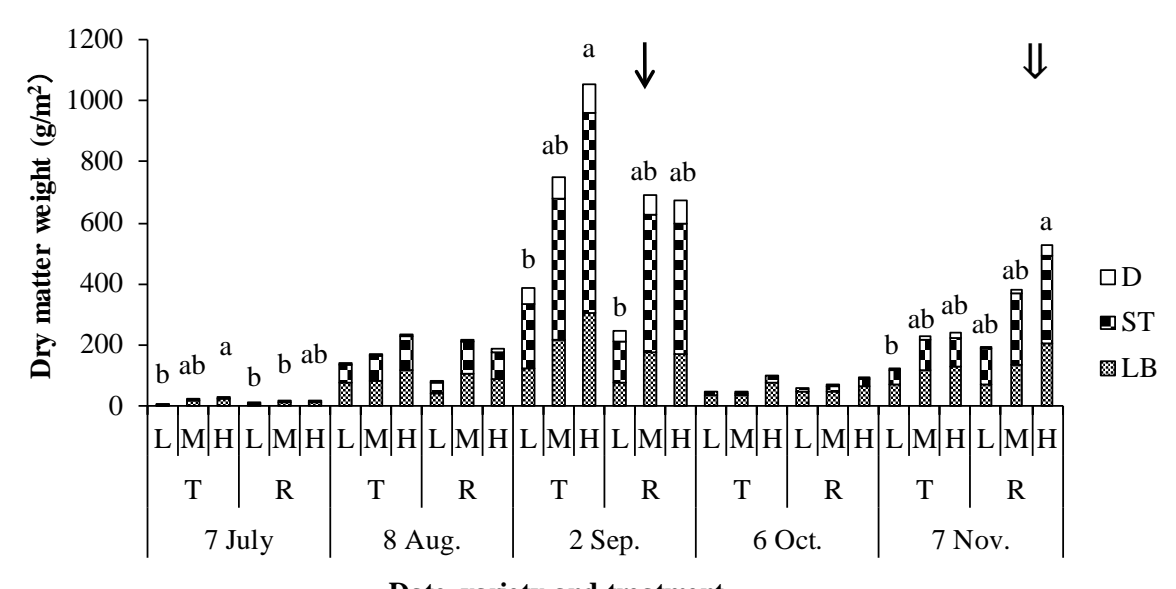

Date, variety and treatment

Figure 3. Changes in dry matter weight of sorghum plants under different sowing rate on 6 June 2014. Sowing rate: $0.5(\mathrm{~L}), 1.0(\mathrm{M})$ and $1.5(\mathrm{H}) \mathrm{g}$ per $\mathrm{m}^{2}$. Leaf blade (LB), Stem (ST) and dead leaves (D). Symbols with different letters denote significant difference among treatments on the same date at the $5 \%$ level. T: Tarzan, R: Roll-king II. $\downarrow$ : 1 st cutting, $\Downarrow$ : 2nd cutting. 


\subsection{Growth Rate of Plant Length and Crop Growth Rate}

In "Tarzan", growth rate of plant length tended to be higher than "Roll-king II" at the first cutting, except for in the $\mathrm{M}$ treatment (Table 1). At the second cutting, the growth rate of plant length of "Tarzan" was lower than "Roll-king II" in all treatments, averaging $1.1 \mathrm{~cm} \mathrm{day}^{-1}$ (Table 1). Crop growth rate of "Tarzan" tended to increase significantly with increase in sowing rate at the first cutting, while the difference among treatments decreased at the second cutting (Figure 4(a)). In "Roll-king II", crop growth rate was higher in the M and $\mathrm{H}$ treatments than in the L treatment at the first cutting and tended to increase with increase in sowing rate at the second cutting, though the difference among treatments was not significant (Figure 4(b)).

\section{Discussion}

The observed annual dry matter yield of "Tarzan" and "Roll-king II" (1298 and $1209 \mathrm{~g} \cdot \mathrm{m}^{-2}$, respectively), were lower than in previous reports for "Tarzan" $\left(2114 \mathrm{~g} \cdot \mathrm{m}^{-2}\right)$ [15] and for "Roll-king II" (2039 - $\left.2800 \mathrm{~g} \cdot \mathrm{m}^{-2}\right)$ [16] [17]. The lower yield observed in the present study was suggested to be due to two major reasons. The first was the difference in sowing methods, with the previous method using the over casting method and the current study the ridge (row) sowing method. The objective of the current study was to determine the suitability of a low sowing rate of "Tarzan" in southern Kyushu; therefore, the examined sowing rate was almost one-fifth to one-third of the traditional sowing rate of the commercial sudangrass cultivars in Japan. The seed weight of "Tarzan", estimated from 1000 seed weight, was $30 \mathrm{~g}$, so the weight per seed was $30 \mathrm{mg}$. Therefore, the 0.5 (L), $1.0(\mathrm{M})$, and $1.5 \mathrm{~g} \cdot \mathrm{m}^{-2}(\mathrm{H})$ levels of the examined sowing rates were calculated as equivalent to $16.7,33.3$, and 50.0 seeds $\mathrm{m}^{-2}$, respectively. The number of seeds per unit length $\left(\mathrm{m}^{-1}\right)$ were calculated as $8.3,16.7$, and 25.0

Table 1. Growth rate of plant length in sorghum.

\begin{tabular}{cccccc}
\hline & \multicolumn{5}{c}{ Growth rate of plant length $(\mathbf{c m} / \mathbf{d a y})$} \\
\cline { 2 - 6 } Treatment & \multicolumn{2}{c}{ 1st cutting } & & \multicolumn{2}{c}{ 2nd cutting } \\
\cline { 2 - 6 } & $\mathbf{T}$ & $\mathbf{R}$ & $\mathbf{T}$ & $\mathbf{R}$ \\
\hline L & 1.90 & 1.78 & 1.13 & 1.54 \\
M & 1.82 & 1.93 & 1.11 & 1.46 \\
H & 1.83 & 1.78 & 1.11 & 1.46 \\
\hline
\end{tabular}

Sowing rate: 0.5 (L), 1.0 (M) and $1.5(\mathrm{H}) \mathrm{g}$ per $\mathrm{m}^{2}$. T: Tarzan, R: Roll-king II.
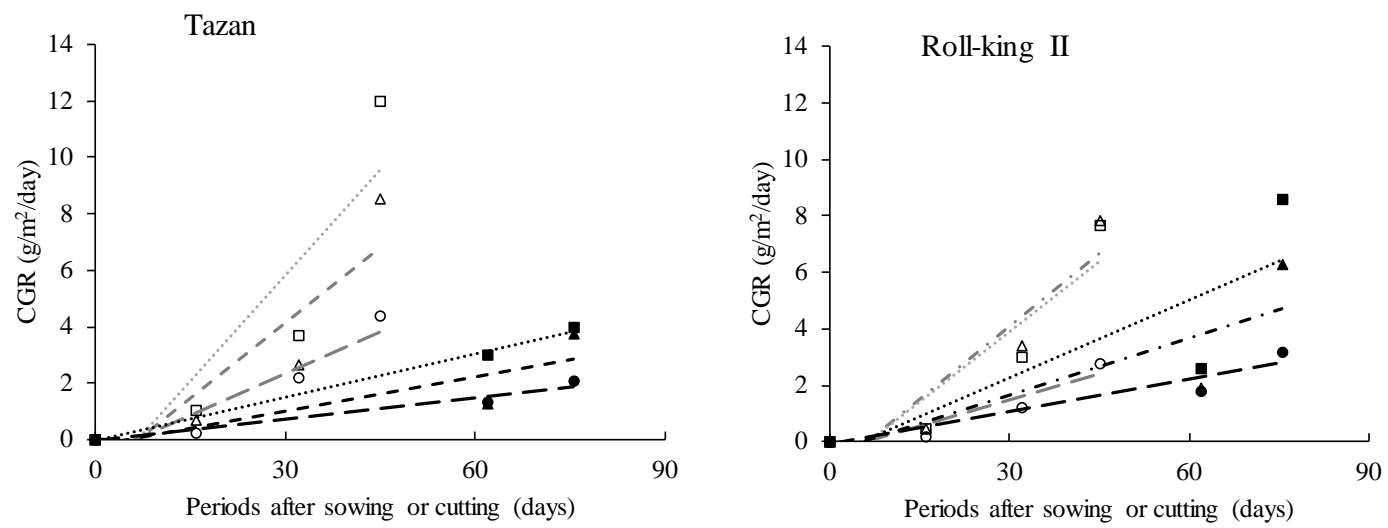

Figure 4. Changes in crop growth rate (CGR) of sorghum plants under different sowing rate on 6 June, 2014. First-cut: L $(\circ), M(\triangle)$, H ( $\square)$, Second-cut: L $(\bullet), M(\Delta), H(\bullet)$. Tarzan at the 1st-cut plants: H $(y=0.250 x-$ $\left.1.644, \mathrm{R}^{2}=0.831\right), \mathrm{M}\left(\mathrm{y}=0.178 \mathrm{x}-1.176, \mathrm{R}^{2}=0.805\right), \mathrm{L}\left(\mathrm{y}=0.0986 \mathrm{x}-0.594, \mathrm{R}^{2}=0.891\right)$. Tarzan at the 2nd-cut plants: $\mathrm{H}\left(\mathrm{y}=0.0513 \mathrm{x}-0.0279, \mathrm{R}^{2}=0.995\right), \mathrm{M}\left(\mathrm{y}=0.0406 \mathrm{x}-0.187, \mathrm{R}^{2}=0.741\right), \mathrm{L}(\mathrm{y}=0.0254 \mathrm{x}-$ $\left.0.0395, R^{2}=0.962\right)$. Roll-king II at the 1 st-cut plants: $H\left(y=0.166 x-0.107, R^{2}=0.849\right), M(y=0.173 x-$ $\left.1.07, \mathrm{R}^{2}=0.873\right), \mathrm{L}\left(\mathrm{y}=0.0615 \mathrm{x}-0.365, \mathrm{R}^{2}=0.881\right)$. Roll-king II at the 2nd-cut plants: $\mathrm{H}(\mathrm{y}=0.0919 \mathrm{x}-$ $\left.0.471, R^{2}=0.699\right), M\left(y=0.0670 x-0.341, R^{2}=0.701\right), L\left(y=0.0381 x-0.0874, R^{2}=0.920\right)$. 
seeds under the fixed 50-cm row distance in the L, M, and $\mathrm{H}$ levels, respectively, assuming 12, 6, and $4 \mathrm{~cm}$, respectively, of intra-row or between-seed distance if seeds were evenly planted. These sowing methods have wider inter-row and narrower intra-row distances than the overcasting method used in previous research. The high competitiveness of the intra-row plant relationship might inhibit growth at later growth stages.

The second reason was the heavy rainfall in June within 4 weeks after sowing at $600 \mathrm{~mm}$, which was equivalent to almost one-fourth of the annual rainfall in Miyazaki. The experiments were conducted in a new field that was established almost 2 months before sowing and was located in low-lying land, easily submerged after heavy rainfall. Sorghum is more tolerant to water-lodging than maize [11]; however, its emergence can be poor when seeds are submerged, resulting in poor establishment and lower plant density, leading to lower dry matter yield compared with previous research.

The temperature averaged $22.6^{\circ} \mathrm{C}$ in the current study, which were similar to normal for the site. The growth rate of sudangrass exhibits a linear response to the temperature range when regulated at $17.9^{\circ} \mathrm{C}-27.9^{\circ} \mathrm{C}$ [18], suggesting that no adverse effect would be expected due to temperature. However, before the first cutting on 2 September, sorghum plants were influenced by typhoons twice, leading to leaf drop, decline of photosynthetic activity, and reduction of the growth rate of the first-cut plants.

A low sowing rate of sorghum should reduce the dry weight [19] but with no positive effect on yielding ability [20] [21]. Under the current sowing rates of $0.5,1.0$, and $1.5 \mathrm{~g} \cdot \mathrm{m}^{-2}$, the linear increase in dry matter yield strongly suggested an optimum sowing rate of between $1.0-1.5 \mathrm{~g} \cdot \mathrm{m}^{-2}$ in "Tarzan" under humid and warmer conditions.

\section{Conclusion}

In the current study, the growth attributes and dry matter yield of newly introduced sorghum genotype "Tarzan" were partly affected by high humidity and warm temperature in Japan, even though the negative effects appeared to a smaller extent than in "Roll-king II". These findings suggest that "Tarzan" can be introduced to southern Kyushu as forage. The dry matter yield in the $\mathrm{H}$ treatment at a $1.5 \mathrm{~g} \cdot \mathrm{m}^{-2}$ sowing rate was significantly higher than in the L treatment of $0.5 \mathrm{~g} \cdot \mathrm{m}^{-2}$, although no significant difference appeared above the M level (1.0 $\mathrm{g} \cdot \mathrm{m}^{-2}$ ). Thus, the optimum sowing rate of "Tarzan" should be between 1.0 to $1.5 \mathrm{~g} \cdot \mathrm{m}^{-2}$ in Kyushu, Japan, which is one-fifth to one-third the rate of the traditional sudangrass cultivar in Japan.

\section{References}

[1] Ministry of Agriculture, Forestry and Fisheries (MAFF) (2013) Shiro wo meguru jousei. MAFF, Tokyo. http://www.maff.go.jp/j/chikusan/sinko/lin/l siryo/pdf/siryou data 2506.pdf\#search='\%E9\%A3\%BC\%E6\%96\%99\%E 3\%82\%92\%Е3\%82\%81\%E3\%81\%90\%Е3\%82\%8B\%E6\%83\%85\%Е5\%8B\%A2+2013'

[2] Kato, N. (2011) Corn No-Till Cultivation in Kyushu Region of Japan. Journal of Japanese Society Grassland Science, 57, 172-175.

[3] Kanno, T., Morita, S., Sasaki, H. and Nishimura, K. (2014) Recent Situation and Future Prediction for Areas Suitable for Double Cropping of Corn (Zea mays L.) Production in Japan’s Kanto Region. Japanese Journal of Grassland Science, 60, 161-166. http://doi.org/10.14941/grass.60.161

[4] Undersander, D.J., Kelling, K.A. and Doll, J.D. (1990) Forage Sorghum. Corn Agronomy. http://corn.agronomy.wisc.edu/Crops/SorghumForage.aspx

[5] Fageria, N.K., Baligar, V.C. and Jones, C.A. (2010) Growth and Mineral Nutrition of Field Crops. CRC Press, New York, 343-361. http://dx.doi.org/10.1201/b10160-12

[6] Bekele, W.A., Fiedler, K., Shirigani, A., Schnaubelt, D., Windpassinger, S. and Uptmoor, R. (2014) Unravelling the Genetic Complexity of Sorghum Seedling Development under Low-Temperature Conditions. Plant, Cell and Environment, 37, 707-723. http://onlinelibrary.wiley.com/doi/10.1111/pce.12189/pdf http://dx.doi.org/10.1111/pce.12189

[7] Peacock, J.M. (1982) Response and Tolerance of Sorghum to Temperature Stress. In: House, L.R., et al., Eds., Sorghum in the Eighties. Proceedings of the International Symposium on Sorghum, Patancheru, 2-7 November 1981, International Crops Research Institute for the Semi-Arid Tropics (ICRISAT), Hyderabad, 143-159.

[8] Ercoli, L., Mariotti, M., Masoni, A. and Arduini, I. (2004) Growth Responses of Sorghum Plants to Chilling Temperature and Duration of Exposure. European Journal of Agronomy, 21, 93-103.

http://dx.doi.org/10.1016/S1161-0301(03)00093-5 
[9] Razmi, Z., Hamidi, R. and Pirasteh-Anosheh, H. (2013) Seed Germination and Seedling Growth of Three Sorghum (Sorghum bicolor L.) Genotypes as Affected by Low Temperatures. International Journal of Farming and Allied Sciences, 2, 851-856. http://ijfas.com/wp-content/uploads/2013/10/851-856.pdf

[10] Mahmood, A. and Honermeier, B. (2012) Chemical Composition and Methane Yield of Sorghum Cultivars with Contrasting Row Spacing. Field Crops Research, 128, 27-33. http://www.sciencedirect.com/science/article/pii/S037842901100414X http://dx.doi.org/10.1016/j.fcr.2011.12.010

[11] Nordquist, P.T. and Rumery, M.G.A. (1967) Corn and Sorghum Silage for Lactating Dairy Cows. Journal of Dairy Science, 50, 1255-1261. http://dx.doi.org/10.3168/jds.S0022-0302(67)87609-4

[12] Lubis, A.D. and Kumagai, H. (2007) Comparative Study on Yield and Chemical Composition of Maize (Zea mays L.) and Sorghum (Sorghum bicolor Moench) Using Different Levels of Manure Application. Animal Science Journal, 78, 605-612. http://onlinelibrary.wiley.com/doi/10.1111/j.1740-0929.2007.00481.x/epdf http://dx.doi.org/10.1111/j.1740-0929.2007.00481.x

[13] Windpassinger, S., Friedt, W., Frauen, M., Snowdon, R. and Wittkop, B. (2015) Designing Adapted Sorghum Silage Types with an Enhanced Energy Density for Biogas Generation in Temperate Europe. Biomass and Bioenergy, 81, 496-504. http://dx.doi.org/10.1016/j.biombioe.2015.08.005

[14] KWS SAAT SE (2014) KWS TARZAN. Sichert hohe Erträge bei guter Erntbarkeit. http://www.kws.de/aw/KWS/germany/Produkte/Sorghum/Sortenuebersicht/Sorghum-Sorten-Deutschland/ dvjc/KWSTARZAN/

[15] Zeise, K. (2013) Sorghum in Hochform. Bayerisches Landwirtschaftliches Wochenblatt, 7, 54-56. http://www.tfz.bayern.de/mam/cms08/rohstoffpflanzen/dateien/blw_zeise_sorghum.pdf\#search='Sorghum+in+Hochform

[16] Nagasaki Experimental Stock Farm (2006) Selection Test of Forage Crops Favorable Varieties. Nagasaki Experimental stock Farm Statement of Service, Nagasaki, 29-30.

[17] Endou, N., Yoshihira, T., Nakui, T. and Kosaka, S. (2009) The Differences between the Annual of Dry Matter Production and Nutrient Yield in Sorghum Cultivars Adapted to Hokkaido. Hokkaido Society of Livestock and Grassland Science, 43, 47.

[18] Fukagawa, S., Ishii, Y., Sato, K., Kobayashi, R. and Hattori, I. (2014) Thermal Response of Seedling Growth in Tropical Grasses in Controlled and Field Environments of Northern Kyushu, Japan. American Journal of Plant Physiology, 9, 110-116. http://scialert.net/qredirect.php?doi=ajpp.2014.110.116\&linkid=pdf http://dx.doi.org/10.3923/ajpp.2014.110.116

[19] Tsuru, M., Kasuga, S., Watanabe, H. and Momose, Y. (2002) The Cultural Weed Control Technic of Broadcasting and Planting Density in High Digestibility Sorghum “Hazuki”. Japan Journal of Grassland Science, 48, 96-97.

[20] Marsalis, M.A., Angadi, S.V. and Contreras-Govea, F.E. (2010) Dry Matter Yield and Nutritive Value of Corn, Forage Sorghum, and BMR Forage Sorghum at Different Plant Populations and Nitrogen Rates. Field Crops Research, 116, 52-57. http://www.sciencedirect.com/science/article/pii/S0378429009003190 http://dx.doi.org/10.1016/j.fcr.2009.11.009

[21] Sinder, J.L., Raper, R.L. and Schwab, E.B. (2012) The Effect of Row Spacing and Seeding Rate on Biomass Production and Plant Stand Characteristics of Non-Irrigated Photoperiod-Sensitive Sorghum (Sorghum bicolor (L.) Moench). Industrial Crops and Products, 37, 527-535. http://www.sciencedirect.com/science/article/pii/S0926669011003293 http://dx.doi.org/10.1016/j.indcrop.2011.07.032 